\title{
Adoption of Inflation Targeting and Tax Revenue Performance in Emerging Market Economies: An Empirical Investigation
}

\author{
Yannick LUCOTTE* \\ Laboratoire d'Economie d'Orléans \\ Université d'Orléans, CNRS
}

\begin{abstract}
Inflation targeting is a monetary policy framework which was adopted by several emerging countries over the last decade. Previous empirical studies suggest that inflation targeting has significant effects on either inflation or inflation variability in emerging targeting countries. But, by reinforcing the disinflation process and so, by reducing drastically seigniorage revenue, the adoption of this monetary policy framework could also affect the design of fiscal policy. In a recent paper, Minea and Villieu (2009a) show theoretically that inflation targeting provides an incentive for governments to improve institutional quality in order to enhance tax revenue performance. In this paper, we test this theoretical prediction by investigating whether the adoption of inflation targeting affects the fiscal effort in emerging markets economies. Using propensity score matching methodology, we evaluate the "treatment effect" of inflation targeting on fiscal mobilization in thirteen emerging countries that have adopted this monetary policy framework by the end of 2004. Our results show that, on average, inflation targeting has a significant positive effect on public revenue collection.
\end{abstract}

Keywords: Inflation targeting, Public revenue, Treatment effect, Propensity score matching, Emerging countries.

JEL Codes: E5, E6, H2.

\footnotetext{
* LEO - Université d'Orléans, UMR CNRS 6221, Faculté de Droit d'Economie et de Gestion, Rue de Blois, BP 6739 - 45067 Orléans Cedex 2, France.Email: yannick.lucotte@etu.univ-orleans.fr.
} 


\section{Introduction}

Since its adoption by Chile in 1990, the monetary policy framework known as inflation targeting (hereafter IT) have been implemented by an increasing number of other emerging countries. Thus, by the end of 2009 , there were nineteen emerging market economies which have adopted this monetary policy strategy, predominantly Latin American and Central and Eastern European countries. Moreover, beside these countries, several other emerging countries have expressed the wish to switch to IT at short-medium term ${ }^{2}$.

According to Amato and Gerlach (2002), this evolution of monetary policy constitutes the most important change in the framework of monetary policy since the collapse of the Bretton Woods system. Two main arguments can be advanced to explain the high popularity of IT in emerging economies. First, the choice of IT constitutes a pragmatic response to difficulties of central banks in conducting their monetary policy using an exchange rate peg or monetary aggregate as an intermediate target. Second, this choice can be explained by the relative benefits of this monetary policy framework on economic performances observed in industrialized and emerging economies that have adopted IT, and corroborated by a significant body of empirical literature. For instance, Lin and Ye (2009) find evidence for a large sample of developing and emerging countries that IT improves economic performance as measured by the level and variability inflation ${ }^{3}$.

IT is defined as a framework for monetary policy characterized by the public announcement of official quantitative targets and by a commitment that low and stable inflation is the primary long-run goal of monetary policy (Bernanke et al., 1999). More precisely, Mishkin (2000) lists five components to an IT framework: (i) a public announcement of a mediumterm numerical inflation target; (ii) an institutional commitment to price stability as the primary monetary policy objective; (iii) an information-inclusive strategy to set monetary policy instruments; (iv) an increased level of transparency for the conduct of monetary policy; $(v)$ and, an increased accountability of central bank for attaining its inflation objectives. Thus, this monetary policy strategy requires much more than a public announcement of numerical

\footnotetext{
${ }^{2}$ These countries are: Albania, Algeria, Argentina, Armenia, Croatia, Dominican Republic, Georgia, Honduras, Jamaica, Kazakhstan, Kenya, Kyrgyzstan, Mauritius, Mongolia, Russia, Sri Lanka, Tanzania, Uganda, and Venezuela (Pétursson, 2004).

${ }^{3}$ Note however that Brito and Bystedt (2010) find no evidence that IT improves economic performances in emerging countries.
} 
inflation targets. The main advantage of an IT framework is the increase of monetary policy discipline, transparency and coherence (Bernanke et al., 1999; Faust and Henderson, 2004). Furthermore, according to Bernanke et al. (1999), IT offers a framework of "constrained discretion" where the official target imposes the constraint, and the discretion is the scope for monetary authorities to take into account short-term disturbances to output or financial stability. This flexibility in the conduct of monetary policy is particularly important for emerging economies that are often adversely affected by external shocks (Fraga et al., 2003).

These considerations suggest therefore that the success and the sustainability over the medium term of IT entail the fulfillment of several economic and institutional conditions. The literature has identified some preconditions that countries should theoretically satisfy before adopting $\mathrm{IT}^{4}$. However, the experience of emerging countries shows that the non fulfillment is not in itself an impediment to the adoption and success of this monetary policy framework. This emphasizes especially that the implementation of IT is a gradual process with economic and institutional reforms before and after the official adoption of this monetary policy framework. Indeed, as illustrated in Batini and Laxton (2006), we observed in some emerging countries that the adoption of IT has been associated with rapid improvements in institutional and technical structures.

Besides these post-IT technical and institutional changes, we think that the adoption of IT by emerging market economies could also affect the design of fiscal policy, and more particularly the design of tax policy. Indeed, by strengthening the central bank independence and by giving the monetary authority a clear mandate for low inflation, the IT regime deprives the government of seigniorage revenue which is an important source of public revenue in developing and emerging countries. Consequently, we can expect that the government will attempt to enhance its tax revenue collection in order to recoup the loss of inflation tax revenue. In a recent paper, Minea and Villieu (2009a) address this question and show theoretically that a tighter monetary policy, i.e. a low inflation target, encourages the government to enhance the performance of tax administration.

\footnotetext{
${ }^{4}$ These preconditions have been especially underlined in the literature on IT in emerging market economies, such as Masson et al. (1997), Mishkin (2000), Amato and Gerlach (2002), and Carare et al. (2002). These requirements include in particular an independent, transparent and accountable central bank with a clear price stability mandate, a sound fiscal policy, a well-developed financial market, a flexible exchange rate regime, relatively low inflation rates, and well-developed statistic and econometric models to understand monetary policy transmission mechanisms and to forecast inflation.
} 
Therefore, the aim of this paper is to empirically test this theoretical prediction by investigating whether the adoption of IT has encouraged the governments of emerging countries to raise domestic tax revenue. To the best of our knowledge, no previous empirical study has tried to investigate this question.

The remainder of the paper is organized as follows. Section 2 outlines the channels through which IT could affect tax policy in emerging economies. The econometric model and the data are described in section 3, while our empirical results are discussed in section 4 . Section 5 concludes.

\section{Inflation targeting and tax policy in emerging economies}

There exists a voluminous theoretical literature on the interaction of monetary and fiscal policies. This literature suggests in particular that the delegation of monetary policy to an independent and more conservative central bank should affect the design of fiscal policy (see e.g., Masciandaro and Tabellini, 1987; Castellani and Debrun, 2001; Montiel, 2003). Indeed, the establishment of an independent monetary authority with a clear mandate for price stability deprives the government of future inflation tax revenue and so, induces it to a greater fiscal discipline. This is particularly true for developing and emerging countries, where seigniorage represents an important source of revenue for governments (World Economic Outlook, 2001). Using a dataset covering a large sample of developing countries, Lucotte (2009) finds relatively robust evidence for the negative relationship between central bank independence and budget deficits predicted by the theory. Furthermore, by giving the monetary authority a legislated objective of price stability, Gerlach (1999) argues that IT can be viewed as a substitute for central bank autonomy. Accordingly, under an IT framework, seigniorage is constrained through a visible "rule", and the government is induced to conduct a more responsible fiscal policy.

Concretely, to reduce its fiscal deficit, a budgetary authority has two complementary options: restrain its spending or/and increase its revenue. On the expenditure side, the government can undertake measures to reduce its structural spending and improve allocative efficiency of public expenditure. In emerging markets, over the last two decades, a common measure to consolidate fiscal accounts consisted of privatizing or reforming state-owned firms (Montiel, 2003). On the revenue side, the government can implement reforms to enhance the 
performance of tax administration, i.e. its capability to impose and collect taxes efficiently. Thus, the implementation of such tax reforms is likely to generate more revenues at a given level of economic activity and so, allows to recoup the substantial loss of seigniorage revenue due to a tighter monetary policy.

Following this logic, Minea and Villieu (2009a) show theoretically that a tighter monetary policy should induce the government to improve institutional quality in order to limit the erosion of tax revenue ${ }^{5}$. Extending the model developed by Huang and Wei (2006) by modifying the principal-agent setup and by incorporating an indicator of financial development and a social welfare function, they conclude that, conditionally to the cost of institutional reforms ${ }^{6}$, pursue a low inflation target encourages the government to increase the performance of its tax collection system. Therefore, the adoption of IT in emerging countries is expected to exert a positive effect on tax revenue collection.

More precisely, Minea and Villieu (2009a) consider a model in which the government, to finance public expenditures, has two sources of revenue: taxes on output and an inflation tax (i.e. seigniorage). In addition, the authors introduce in the government budget constraint two kinds of revenue leakage: a leakage in tax revenue captured by the degree of institutional quality and, a leakage in seigniorage revenue captured by the degree of development of the financial sector. Indeed, according to their specification, countries with poor institutional quality are not able to establish effective tax systems and so, these economies are characterized by a persistent weakness in tax collection. Inversely, countries with a sound tax administration exploit their tax base more fully, and the leakage of tax revenue is weak. Concerning the leakage in seigniorage revenue, the authors introduce in the model an indicator of financial development to capture the fact the banking system's share of seigniorage revenue relative to that of the central bank increases with the level of financial development. In other words, the higher the degree of financial development is, the lower the seigniorage revenue as a source of government finance is ${ }^{7}$. Therefore, in line with Cukierman

\footnotetext{
${ }^{5}$ The literature identifies many causes of poor tax administration in developing countries. These causes are principally: $(i)$ a high level of taxpayers' noncompliance and tax evasion because the tax system is perceived as unfair, and there is a lack of transparency in the use of public funds; (ii) a high corruption in the tax administration due to low wages in the public sector compared to the private sector, and a low probability of detection and punishment for corruption; and, (iii) a large informal sector.

${ }^{6}$ According to Huang and Wei (2006, p. 248), "the cost could be in the form of a loss of economic rents that officials enjoy, or a stiffened resistance from powerful special interest groups that have been benefiting from corruption and lost tax revenue”.

${ }^{7}$ See notably Minea and Villieu (2009b) and Ehrhart et al. (2009) for most details concerning this assumption. Moreover, note that dollarization implies also a loss of seigniorage revenue for the government. Nonetheless,
} 
et al. (1992), Minea and Villieu (2009a) conjecture that economies characterized by weak tax administrations and low developed financial markets will use extensively seigniorage as a source of government revenue rather than "conventional" tax. Moreover, as Huang and Wei (2006), their model considers a two-step game with three agents: the central bank, the fiscal authority, and a "supra-authority" (i.e. the society). The sequence of actions is nonetheless reversed, and the timing of the model is as follows: in the first step, the "supra-authority" (acting as the principal) chooses the "monetary regime" in order to maximize the social welfare function; in the second step, the central bank (the agent) chooses the inflation rate and the government the tax rate and the level of effort in enhancing the quality of institutions that maximize the government's objective function. More precisely, in the case of IT framework, the supra-authority sets the inflation target that the monetary authority must fulfill.

The model developed by Minea and Villieu (2009a) exhibits two interesting results. First, by finding an inverse relationship between the level of effort and the inflation target, the authors show that the lower the inflation target is, the higher the government's effort in enhancing the quality of its institutions will be. In other words, by setting a lower inflation target, the "supraauthority" encourages the fiscal authority to intensify its efforts to implement a more efficient tax-collecting administration in order to recoup the loss of seigniorage revenue due to a tighter monetary policy. Therefore, this result joins theoretical and empirical arguments presented above that conclude that a greater degree of central bank independence may influence the government to fiscal discipline. Nonetheless, this effort in strengthening institutional quality will depend on the cost bearing by the government. To take into account this coast, the authors define corner solutions and show that the values of thresholds depend on the monetary policy, and more precisely on the level of inflation target. Effectively, a decrease in the inflation target reduces the interval in which government's effort is minimal and increases the interval in which the effort in improving institutional quality is maximal.

To conclude, it is important to note that the incentive of the government to improve the collection of tax revenue could be nonetheless diminished by a significant decrease of inflation rate. Indeed, empirical literature has provided evidence that tax revenue is negatively affected by inflation, the so-called Olivera-Tanzi effect (Tanzi, 1992). This inverse relationship is usually explained by the fact that the real value of tax revenue is eroded by

according to Armas and Grippa (2006), Peru is the only highly financially dollarized economy that has adopted IT. 
inflation, since it exists for some tax categories a time-lag between the date of imposition and the effective collection of these taxes ${ }^{8}$. Therefore, by theoretically maintaining inflation at low levels, and therefore by increasing the real value of tax revenue, IT may attenuate the government's tax collection effort. However, in the greatest number of emerging economies, IT was adopted after a disinflation process. So, we expect that this inverse Olivera-Tanzi effect is relatively marginal in these countries.

\section{Data and methodology}

To investigate whether the adoption of IT encourages the government to increase domestic tax revenue, we implement the propensity score matching (hereafter PSM) methodology developed by Rosenbaum and Rubin (1983) and Heckman et al. (1998). This method is becoming increasingly popular in microeconometrics in order to assess the performance of development programs, such as school or health programs. Although still little used in macroeconomic studies, the PSM approach has nevertheless been recently used by Vega and Winkelried (2005) and Lin and Ye $(2007,2009)$ to assess the impact of IT adoption on the level and variability of inflation in developed and emerging economies.

Our panel dataset consists of thirty emerging market countries, inflation targeters and noninflation targeters, over the period of 1980-2004 ${ }^{9}$. The data are drawn from various sources, including in particular the World Bank's World Development Indicators 2008.

\subsection{Data $^{10}$}

Independent variable and sample countries. The independent variable of interest is a binary variable taking the value 1 if a country operates with an IT framework at the year $t$, and 0 otherwise. In this paper, we adopt the classification of IT countries proposed by Levya (2008), which tabulates two IT adoption dates for each country having adopted this monetary policy framework: one corresponding to a partial adoption $\left(I T_{-} P A\right)$ and the second to a fully-fledged

\footnotetext{
${ }^{8}$ However, note that the Olivera-Tanzi effect was mainly observed in hyperinflation countries.

${ }^{9}$ The data are not available for all countries on the whole period, so we use an unbalanced panel data. The list of countries that constitute our sample is given in Table 1.

${ }^{10}$ See Appendix A for variables definitions and sources.
} 
adoption $\left(I T \_F F\right)^{11}$. According to this classification, our sample of IT emerging economies is composed of Brazil, Chile, Colombia, Czech Republic, Hungary, Israel, Mexico, Peru, Philippines, Poland, South Africa, South Korea and Thailand. Concerning the control group, i.e. the non-IT countries, we consult the Standard \& Poor's Emerging Market Index, the Morgan Stanley Capital International Emerging Market Index, and the IMF's International Capital Markets Department's list of emerging markets. Following Joyce and Nabar (2009), we consider the countries which appear on at least two of these three lists ${ }^{12}$. Table 1 lists the thirteen targeting and the seventeen non targeting countries, and the years in which IT countries have adopted this monetary policy framework.

Table 1: Samples countries and dates of IT adoption

\begin{tabular}{|c|c|c|}
\hline \multicolumn{3}{|c|}{ Inflation targeting countries } \\
\hline & Partial adoption & Fully-fledged adoption \\
\hline Brazil & 1999 & 1999 \\
\hline Chile & 1991 & 2000 \\
\hline Colombia & 2000 & 2000 \\
\hline Czech Republic & 1998 & 1998 \\
\hline Hungary & 2001 & 2001 \\
\hline Israel & 1992 & 1997 \\
\hline Mexico & 1995 & 2001 \\
\hline Peru & 1994 & 2002 \\
\hline Philippines & 2002 & 2002 \\
\hline Poland & 1999 & 1999 \\
\hline South Africa & 2000 & 2000 \\
\hline South Korea & 1998 & 1998 \\
\hline Thailand & 2000 & 2000 \\
\hline \multicolumn{3}{|c|}{ Non-inflation targeting countries } \\
\hline Argentina & Jordan & Slovak Republic \\
\hline China & Malaysia & Sri Lanka \\
\hline Egypt & Morocco & Turkey \\
\hline Guatemala & Pakistan & Venezuela \\
\hline India & Romania & Zimbabwe \\
\hline Indonesia & Russia & \\
\hline
\end{tabular}

As shown in Table 1, four countries (Chile, Israel, Mexico, and Peru) started using a partial IT framework before switching to a full-fledged IT. In fact, during this transition period, central banks of these countries have maintained an additional nominal anchor for monetary policy (typically an exchange rate band). Moreover, according to Mishkin and Schmidt-Hebbel (2007), a partial IT is also characterized by the non-fulfillment of key preconditions for IT

\footnotetext{
${ }^{11}$ Levya (2008) adopt the "half-year rule": if IT is adopted in the second half of any year $t$, the year $t+1$ is considered as the adoption year.

${ }^{12} \mathrm{We}$ also include in the sample of non-IT countries Guatemala and Romania, which have adopted IT in 2005.
} 
and the non-establishment of operational features of IT (such as publishing inflation reports that contain inflation projections).

Dependent variable. The endogenous variable considered in our study is the total public revenue (excluding grants) as share of Gross Domestic Product (GDP) compiled by the Center for Studies and Research on International Development on the base of International Financial Statistics (IFS) and Government Finance Statistics (GFS) databases, and national statistics. Although most studies use tax revenue, we measure taxation revenue as total public revenue $\left(T A X \_R E V\right)$. Three arguments can be advanced to explain our choice. First, availability of relevant data on domestic tax revenue for developing and emerging countries is relatively limited. Second, in developing and emerging economies, public revenue is principally composed of direct taxes (taxes on income and profit) and indirect taxes (taxes on international trade and domestic taxes on consumption - sales tax, Value-Added tax and excise tax), while non-tax revenue ${ }^{13}$ represents a small part of the public revenue. Third, total public revenue is less sensitive to the substitution effect between the different components of public revenue, i.e. tax revenue and non-tax revenue (Chambas, 2005).

Figure 1a presents a comparison of average total public revenues between IT countries and non-IT countries over different time periods, while figure $1 \mathrm{~b}$ presents a comparison of average total public revenues between pre and post-IT periods for inflation targeters. In figure 1a, we compare firstly average total public revenue in IT and non-IT economies on the overall period (1980-2004), while in specifications (2) and (3) we follow Ball and Sheridan (2003) suggestion to make a comparison between inflation and non-inflation targeters after the adoption (partial and fully-fledged respectively) of this monetary policy framework ${ }^{14}$. The two specifications in figure $1 \mathrm{~b}$ correspond to a comparison of average public revenue between pre and post-IT periods, respectively in the case of a partial adoption (IT_PA) and a fullyfledged adoption $\left(I T \_F F\right)$. Two preliminary results emerge from figures 1a and 1b. First, on average, IT countries have higher levels of public revenue than non-IT economies. Second, in IT countries, average total public revenue tends to increase after the adoption of IT, especially when we consider the fully-fledged adoption date. Hence, this latter result seems to indicate that IT countries have intensified their efforts to collect more public revenue after the implementation of IT.

\footnotetext{
${ }^{13}$ The non-tax revenues include in particular social security contributions, dividends from state firms, rents from government property, fines, penalties, and sales of goods and services.

${ }^{14}$ Ball and Sheridan (2003) suggest to take as the "year of adoption" for non-targeters the mean of the adoption dates in the targeters group. This date is so the same for all non-IT countries, respectively 1998 if we consider partial adoption (specification 2) and 2000 in the case of fully-fledged adoption (specification 3 ).
} 
Figure 1a: Average total public revenue (\% of GDP): IT vs. Non-IT countries

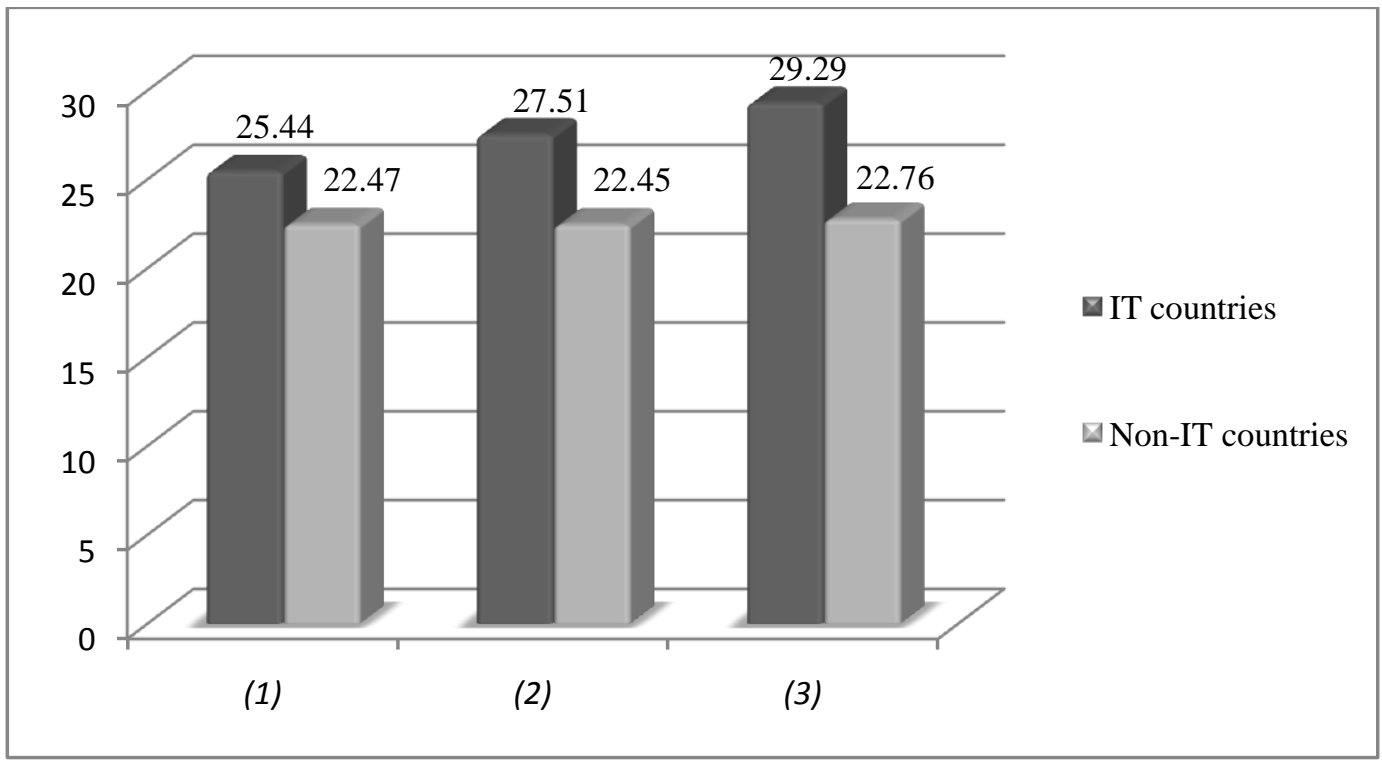

Figure 1b: Average total public revenue (\% of GDP): pre-IT vs. post-IT periods

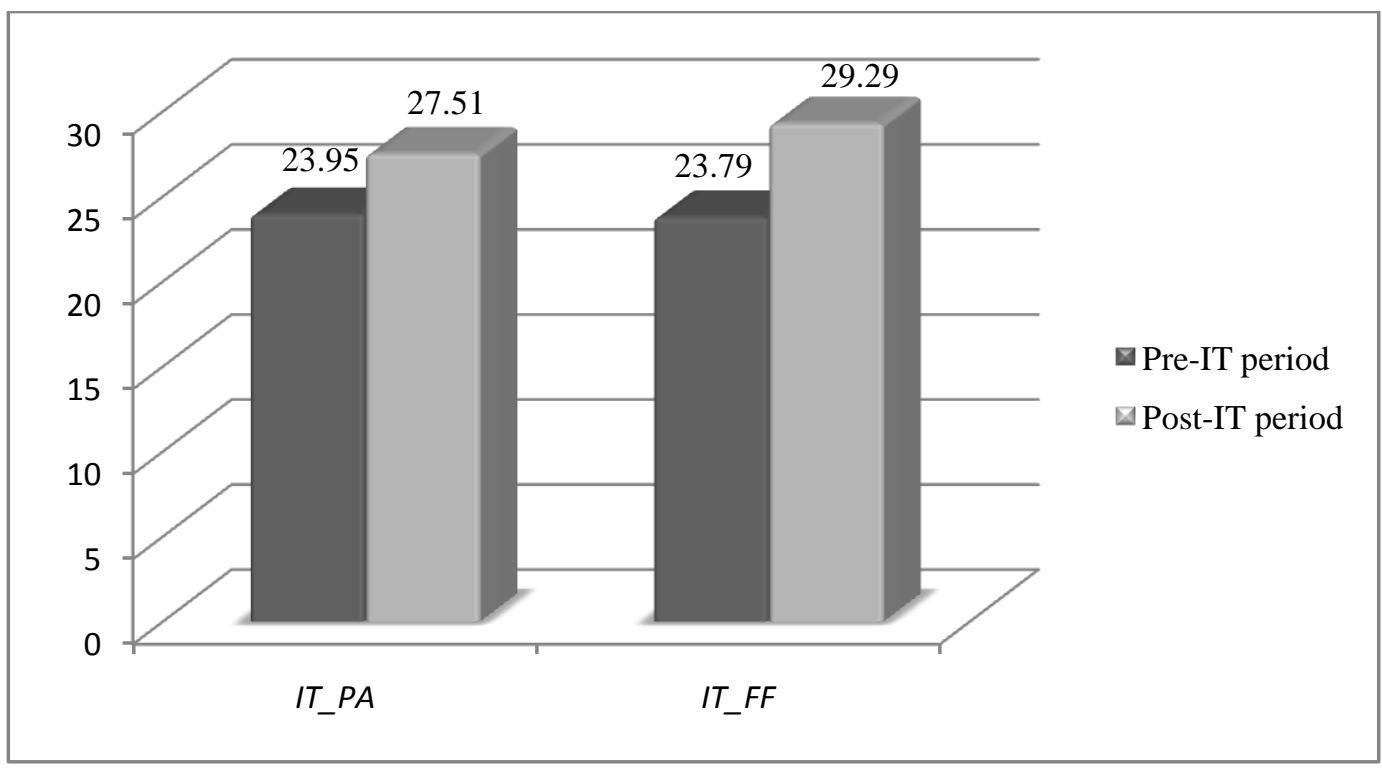

Finally, the other variables of the model are variables that could explain the probability that an emerging country adopts an IT framework. Following Lin and Ye (2009) and the empirical literature devoted to the determinants driving the choice of IT $^{15}$, we choose the following seven variables: the lagged inflation rate $\left(C P I \_l\right)$, the five-year central bank governors turnover rate (TOR_5), the real per capita GDP growth (GDPPCG), the domestic credit to

\footnotetext{
${ }^{15}$ See Pétursson (2004) for a detailed survey of empirical literature.
} 
private sector to GDP (PCRED), the de facto exchange rate regime $(E X C H)$, the trade openness $(O P E N)$, and the number of countries (industrialized and emerging) that have adopted IT at the year $t\left(N U M_{-} I T\right)$. We expect the first two variables to be negatively correlated with the likelihood of adopting IT, while the other covariates are expected to have a positive effect on this probability.

\subsection{Econometric methodology}

The main challenge of our econometric analysis is to deal with the nature of the independent variable. Indeed, as specified above, the independent variable of interest is binary, and takes the value 1 if a country pursues an IT policy at the year $t$ and 0 otherwise. In the case of our study, the difficulty of evaluating the impact of IT adoption on domestic tax revenue resides in the fact that we cannot observe what would have been this revenue if an inflation targeter has made the choice to not adopt this monetary policy framework. Conversely, it is impossible to observe what would have been domestic tax revenue if a non-inflation targeter has switched to IT.

A simple solution to assess this causal effect, by definition unobservable, would consist in comparing average public tax revenue of IT countries with those of a comparison group of countries which have not adopted IT (canonical model introduced by Rubin, 1974). In doing so, we suppose that our two groups of economies are very similar, such that countries which adopted IT would have had domestic tax revenue similar to those in the comparison group in the absence of IT. However, as we know, emerging countries constitute a relatively heterogeneous group. Thus, such a statistical approach raises the question of selection bias, which can lead to an overestimation of the impact of IT adoption on tax revenue ${ }^{16}$.

In response to this selectivity bias problem, Rosenbaum and Rubin (1983) have developed the PSM methodology. This latter is a non experimental method which consists of matching treated observations with untreated observations on the basis of observed characteristics unaffected by the treatment. The average treatment effect is then calculated as the mean difference in outcomes across these two groups, i.e. treated and untreated. In our case, the "treatment" corresponds to the adoption of IT and the outcome is the domestic tax revenue.

\footnotetext{
${ }^{16}$ In theory, a selection bias can lead to an either underestimation or overestimation. Nonetheless, in our case study, an overestimation of the impact of IT adoption on domestic tax revenue could be expected since to adopt such a monetary policy framework, a country should theoretically fulfill several preconditions. One of them is a sound fiscal policy. So, we can expect that IT emerging countries are also those with a relatively developed tax administration.
} 
Indeed, a country is considered as "treated" if it pursues an IT strategy at the year $t$, and as "untreated" if it not operates with this monetary policy framework at the same period. Finally, concerning the matching, it is conducted on a set of potential determinants associated with a country's choice of IT.

Therefore, the "average treatment effect on treated" (hereafter ATT) can be written as:

$\Delta_{A T T}^{P S M}=E\left[Y_{i t}^{1} \mid T_{i t}=1, p\left(X_{i t}\right)\right]-E\left[Y_{i t}^{0} \mid T_{i t}=0, p\left(X_{i t}\right)\right]$

where $\mathrm{T}$ is the independent variable corresponding to the adoption of IT and $\mathrm{Y}$ is the domestic tax revenue. Thus, $Y_{i t}^{1} \mid T_{i t}=1$ represents the domestic tax revenue observed in a country having adopting IT at the year $t(\mathrm{~T}=1)$ and $Y_{i t}^{0} \mid T_{i t}=0$ the domestic tax revenue observed in the counterfactual. $p\left(X_{i t}\right)$ corresponds to the propensity score, i.e. the probability that conditionally to a set of observable covariates $X$, a country $i$ adopts an IT framework at the period $t$. The propensity score is noted as:

$p\left(X_{i t}\right)=\operatorname{Pr}\left(T_{i t}=1 \mid X_{i t}\right)$

The propensity score is estimated using a binary outcome model (probit or logit) where $X_{i t}$ is a vector of variables corresponding to observed country's characteristics theoretically associated with the choice of adopting IT.

Nevertheless, the PSM approach provides a sound impact assessment only if two assumptions are satisfied. The first is the conditional independence assumption, which means that given a set of observed covariates $X$ unaffected by the treatment, the potential outcomes $\mathrm{Y}$ is independent of treatment assignment $T$. In other words, this means that the choice of adopting IT is independent of the potential outcomes in both situations, adoption or no adoption. Consequently, this implies that the choice of switching to an IT strategy is solely based on observable countries' characteristics and not on unobservable characteristics. Furthermore, in practical terms, this assumption implies that we must observe and include in the vector $X$ all variables that influence simultaneously treatment assignment and potential outcomes. Formally, this hypothesis can be written as:

$\left(\mathrm{Y}_{\mathrm{i}}^{0}, \mathrm{Y}_{\mathrm{i}}^{1}\right) \perp T_{i} \mid X_{i}$

As shown by Rosenbaum and Rubin (1983), the fulfillment of this assumption is fundamental since it allows to match observations on the basis of their propensity score $p\left(X_{i t}\right)$ rather than 
on the whole conditioning variables. The propensity score constitutes then a unidimensionnal "summary" of the covariates. According to Rubin (2007), the fact that the propensity score is independent of the potential outcomes constitutes the main advantage of matching estimators compared with other non experimental methodologies.

The second assumption is the common support condition whose importance has been emphasized by Heckman et al. (1998, 1999). In the case of our study, this condition ensures that we can find for each IT country at the period $t$ a counterfactual in the comparison group of non-IT economies, i.e. an observation with the same or nearby propensity score. Formally, the common support condition means that observations with the same $X$ values have a positive probability of being treated or untreated. Thus, this condition can be written as:

$0<p\left(X_{i t}\right)<1$

This condition implies that the propensity score distribution is not very different in the treatment and the control group. Consequently, the common support condition rules out the phenomenon of perfect predictability of $T$ given $X$ (i.e. the perfect predictability of IT adoption) and so, paradoxically, implies that the binary outcome model must not be "too good" (Brodaty et al., 2007).

By presenting in details the propensity score matching methodology and its relevance for our study, we have seen that the quality of impact analysis depends mainly on the "robustness" of propensity score estimates. Furthermore, the resulting estimate is also affected by the matching criterion used to assign treated and untreated on the basis of the propensity score. For this reason, most of papers use different matching algorithms to assess the effect of treatment ${ }^{17}$. In this paper, following Lin and Ye $(2007,2009)$, we use three PSM algorithms commonly used in the literature:

(i) Nearest-neighbor matching estimator consists of matching each treated observation with an untreated observation that is the closest in terms of propensity score. We consider the one-to-one matching with no replacement $(n=1)$, the three nearest-neighbor matching $(n=3)$, and the five nearest-neighbor matching $(n=5)$;

(ii) Radius matching estimator imposes a threshold on the maximum propensity score distance. We consider three calipers, i.e. three values for maximum distance of

\footnotetext{
${ }^{17}$ See notably Caliendo and Kopeinig (2007) and Khandker et al. (2010) for detailed discussions concerning these algorithms.
} 
untreated observations: a wide radius $(\mathrm{r}=0.04)$, a medium radius $(\mathrm{r}=0.02)$, and tight radius $(\mathrm{r}=0.01)$;

(iii) Kernel matching estimator proposed by Heckman et al. (1998) consists of using a weighted average of all untreated observations to construct the counterfactual match for each treated observation. The weight given to each untreated observation depends on the distance from the treated observation in terms of propensity score. Logically, this weight increases with the convergence in terms of propensity score of untreated observations to the considered treated observation ${ }^{18}$.

\section{Results}

As implicitly shown in the previous section, the estimation process of the average treatment effect of IT on the level of domestic tax revenue includes two steps. The first step consists of estimating the propensity scores with a binary outcome model, while the second step consists of matching treated and untreated observations to estimate the average treatment effect on the treated.

\subsection{Estimating the propensity scores}

To estimate the propensity scores, we use a probit model. The dependent variable is the IT variable. The results are reported in table 2 , in which we distinguish the partial adoption and the fully-fledged adoption of IT. All significant estimated coefficients have the expected signs. We find that the real per capita GDP growth, the de facto exchange rate flexibility, and the number of inflation targeters in the world are positively associated with a greater likelihood of adopting IT, while the turnover rate of central bank governors and the lagged inflation rate are significantly and negatively related with this probability. Concerning the coefficients of domestic credit to private sector and trade openness, they are not statistically significant. The pseudo- $\mathrm{R}^{2}$ is 0.42 and 0.66 in the case of partial adoption and fully-fledged adoption, respectively.

\footnotetext{
${ }^{18}$ The weights for kernel matching are given by: $(i, j)=\frac{K\left(\frac{P_{j}-P_{i}}{a_{n}}\right)}{\sum K\left(\frac{P_{j}-P_{i}}{a_{n}}\right)}$, where $\mathrm{P}_{\mathrm{i}}$ is the propensity score for treated observation $i, \mathrm{P}_{\mathrm{j}}$ is the propensity score for untreated observation $j, \mathrm{~K}($.$) is a kernel function, and \mathrm{a}_{\mathrm{n}}$ is a bandwidth parameter.
} 
Table 2: Probit estimates of propensity scores

\begin{tabular}{lll}
\hline & $\begin{array}{l}\text { IT (partial adoption) } \\
(1)\end{array}$ & $\begin{array}{l}\text { IT (fully-fledged adoption) } \\
(2)\end{array}$ \\
\hline GDPPCG & $0.054^{* *}$ & $0.061^{*}$ \\
& $(0.02)$ & $(0.03)$ \\
CPI_1 & $-0.045^{* * *}$ & $-0.158^{* * *}$ \\
& $(0.01)$ & $(0.03)$ \\
PCRED & -0.00 & -0.003 \\
& $(0.00)$ & $(0.00)$ \\
TOR_5 & -0.468 & $-2.399^{* * *}$ \\
& $(0.48)$ & $(0.82)$ \\
EXCH & $0.289^{* * *}$ & $0.475^{* * *}$ \\
& $(0.03)$ & $(0.06)$ \\
OPEN & -0.003 & 0.003 \\
& $(0.00)$ & $(0.00)$ \\
NUM_IT & $0.091^{* * *}$ & $0.188^{* * *}$ \\
& $(0.01)$ & $(0.03)$ \\
\hline Nb. of observations & 515 & 515 \\
Pseudo-R & 0.42 & 0.66 \\
\hline
\end{tabular}

Note: Constant terms are included but not reported. Standard errors are reported in parentheses. *, **, *** refer to statistical significance at the $10 \%, 5 \%$ and $1 \%$ respectively.

\subsection{Results from matching}

Before turning to the matching estimates ${ }^{19}$, we implement the common support condition which ensures that treated and untreated observations share the same support. In this paper, we use the methodology suggested by Dehejia and Wahba (1999) which consists of dropping treated observations whose the propensity score is higher than the maximum or smaller than the minimum in the control group. The estimated ATTs on the level of public revenue are reported in table 3. The first three columns show the results from nearest-neighbor matching, the columns (4) (5) and (6) report the results from radius matching, and the last column presents the result from kernel matching. The estimated ATTs are all found to be positive and statistically significant. This suggests that, on average, IT has a quantitatively large and statistically significant impact on increasing public revenue in emerging market economies. This result largely supports our hypothesis that the adoption of IT may encourage the government to improve the collection of tax revenue. In particular, as shown in figure 1, the results indicate that the average estimated ATT is larger when we consider the fully-fledged adoption of IT than partial adoption. The average estimated ATT on the level of public

\footnotetext{
${ }^{19}$ Matching estimates are obtained using the Stata module PSMATCH2 developed by Leuven and Sianesi (2003).
} 
revenue across different matching algorithms is about 4.45 in the case of partial adoption and is about 7.95 in the case of fully-fledged adoption. This latter result can nonetheless be explained by the fact that the modernization of tax and customs administrations requires deep reforms which, by definition, take time to produce revenue gains.

Table 3: Matching estimates of treatment effect on the level of public revenue

\begin{tabular}{|c|c|c|c|c|c|c|c|}
\hline & \multicolumn{7}{|c|}{ Matching algorithms } \\
\hline & \multicolumn{3}{|c|}{$\begin{array}{l}\text { Nearest-neighbor } \\
\text { matching }\end{array}$} & \multicolumn{3}{|c|}{ Radius matching } & \multirow{2}{*}{$\begin{array}{l}\text { Kernel } \\
\text { matching } \\
(7)\end{array}$} \\
\hline & $\begin{array}{l}\mathrm{n}=1 \\
(1)\end{array}$ & $\begin{array}{l}n=3 \\
(2)\end{array}$ & $\begin{array}{l}n=5 \\
(3)\end{array}$ & $\begin{array}{l}r=0.04 \\
(4)\end{array}$ & $\begin{array}{l}r=0.02 \\
(5)\end{array}$ & $\begin{array}{l}r=0.01 \\
(6)\end{array}$ & \\
\hline & \multicolumn{7}{|c|}{ Partial adoption } \\
\hline Average Treatment on Treated (ATT) & $\begin{array}{l}\mathbf{3 . 1 5} \\
(1.36)\end{array}$ & $\begin{array}{l}\mathbf{4 . 8 7}^{\text {*****}} \\
(1.52)\end{array}$ & $\begin{array}{l}\mathbf{4 . 9 0}^{\text {**** }} \\
(1.42)\end{array}$ & $\begin{array}{l}\mathbf{4 . 6 1}^{* * * *} \\
(1.42)\end{array}$ & $\begin{array}{l}\mathbf{4 . 4 1}^{* * * *} \\
(1.57)\end{array}$ & $\begin{array}{l}4.66^{* * * *} \\
(1.76)\end{array}$ & $\begin{array}{l}\mathbf{4 . 5 7} \\
(1.34)\end{array}$ \\
\hline $\mathrm{Nb}$. of treated observations on common support & 98 & 98 & 98 & 98 & 85 & 77 & 98 \\
\hline \multirow[t]{2}{*}{$\mathrm{Nb}$. of treated observations off common support } & 2 & 2 & 2 & 2 & 15 & 23 & 2 \\
\hline & \multicolumn{7}{|c|}{ Fully-fledged adoption } \\
\hline Average Treatment on Treated (ATT) & $\begin{array}{l}\mathbf{6 . 5 7} \\
(1.73)\end{array}$ & $\begin{array}{l}\mathbf{7 . 9 4}^{\text {****}} \\
(2.20)\end{array}$ & $\begin{array}{l}\mathbf{7 . 2 9}^{\text {****}} \\
(2.05)\end{array}$ & $\begin{array}{l}\mathbf{8 . 3 5}^{* * *} \\
(2.39)\end{array}$ & $\begin{array}{l}\mathbf{8 . 6 5}^{* * *} \\
(2.59)\end{array}$ & $\begin{array}{l}8.52^{* *} \\
(3.44)\end{array}$ & $\begin{array}{l}\mathbf{8 . 3 6} \\
(2.19)\end{array}$ \\
\hline $\mathrm{Nb}$. of treated observations on common support & 51 & 51 & 51 & 49 & 37 & 30 & 51 \\
\hline $\mathrm{Nb}$. of treated observations off common support & 22 & 22 & 22 & 24 & 36 & 43 & 22 \\
\hline
\end{tabular}

\subsection{Robustness checks}

We check the robustness of our empirical results in three ways. The first is to check whether our results are sensitive to alternative specifications of the probit model. More precisely, we introduce three variables that could simultaneously influence the choice of adopting IT and the level of domestic tax revenue. These variables are: the lagged domestic tax revenue (TAX_REV_1), the Polity2 index (POLITY2) developed by the Polity IV Project and, the government stability index $(G S T A B)$ computed by the International Country Risk Guide (ICRG). The first variable is included to take into account a potential persistence of domestic tax revenue, while a well-developed tax administration is expected to have a positive effect on the probability of adopting IT regime. Indeed, as emphasized above, one of the preconditions for successful IT strategy is a sound fiscal policy, which requires a strengthening of tax administration system and improvements to expenditure control and debt management. Concerning the Polity2 index, it measures the "degree" of democratization in a country. It takes value from -10 (very autocratic) to +10 (very democratic) and is constructed by 
subtracting the "democracy" score from the "autocracy" score ${ }^{20}$. This index, which can be viewed as an overall measure of political stability, is expected to be positively related with the likelihood of adopting IT. Moreover, as shown by Ehrhart (2009), it exists a positive relationship between the level of democracy and the domestic tax revenue in developing countries. Finally, we consider the government stability index, which assesses the government's ability to carry out its declared program(s) and its ability to stay in office. This index takes values from 0 (very low stability) to 12 (very high stability). It is the sum of three subcomponents (government unity, legislative strength, and popular support), each with a maximum score of four points and a minimum score of zero point. Following Gupta (2007), we expect this variable to be positively with the public revenue since efficient reforms in tax administration and so, tax revenue performance, require a relative political stability. Hence, a positive relationship between these three covariates and the probability of adopting IT is expected. The new probit estimates of the propensity scores are presented in the first three columns of table 4. The estimated coefficients of lagged domestic tax revenue and Polity2 index have the expected signs and are significant. Conversely, as can be seen in column (3) of table 3 , the coefficient of the political stability index has the wrong sign but is not statistically significant. Concerning other covariates, the results are very similar to those reported in the table 2 .

Second, we want to check whether our results are robust to different sample periods. We then re-estimate the initial probit model by dropping the pre-1990 observations. Column (4) of table 3 reports the results from this probit regression. Our results do not change for the new sample period. The pseudo- $\mathrm{R}^{2}$ is 0.35 and 0.62 in the case of partial adoption and fullyfledged adoption, respectively.

Finally, we check the robustness of our results by dropping all hyperinflation periods (defined as an annual inflation rate $\geq 40 \%$ ) since some countries of our sample have experienced hyperinflation $^{21}$. Indeed, from an econometric point of view, these extreme values of inflation could bias the results of the probit model and, consequently, the matching estimates. The results from the probit regression are reported in column (5) of table 4. The results are very similar to those reported in the table 2. In particular, the estimated coefficient of inflation rate is still negative and significant at the $1 \%$ level.

\footnotetext{
${ }^{20}$ See the dataset users' manual available at: http://www.systemicpeace.org/inscr/p4manualv2007.pdf for a detail description of this index.

${ }^{21}$ See Appendix B for summary statistics of inflation rate in IT and non-IT countries. The number of dropped observations is 76 .
} 
The matching results based on these new propensity scores are presented in table 5. Most of the estimated ATTs remain positive and statistically significant, even if they are less or not significant when we add the lagged tax revenue and the Polity2 index to the baseline probit model than other specifications. As in table 3, the average estimated ATT is larger when we consider the fully-fledged adoption of IT than partial adoption. The average estimated ATT on the level of public revenue across different matching algorithms is about 3.46 in the case of partial adoption and is about 5.93 in the case of fully-fledged adoption. Thus, our empirical results are relatively robust to alternative specifications of probit model and confirm the empirical prediction of Minea and Villieu (2009a), in the sense that the adoption of IT has a significant positive impact on tax revenue collection. 
Table 4: Probit estimates of propensity scores (robustness checks)

\begin{tabular}{|c|c|c|c|c|c|c|c|c|c|c|}
\hline & \multicolumn{2}{|l|}{$(1)$} & \multicolumn{2}{|l|}{ (2) } & \multicolumn{2}{|l|}{ (3) } & \multicolumn{2}{|l|}{ (4) } & \multicolumn{2}{|l|}{ (5) } \\
\hline & IT_PA & IT_FF & IT_PA & IT_FF & IT_PA & IT_FF & IT_PA & IT_FF & IT_PA & IT_FF \\
\hline \multirow[t]{2}{*}{ GDPPCG } & $0.052 * *$ & 0.045 & $0.058 * *$ & 0.017 & $0.053 * *$ & $0.059^{*}$ & $0.054 * *$ & $0.061^{*}$ & $0.047 * *$ & $0.061^{*}$ \\
\hline & $(0.02)$ & $(0.04)$ & $(0.02)$ & $(0.04)$ & $(0.02)$ & $(0.03)$ & $(0.02)$ & $(0.03)$ & $(0.02)$ & $(0.03)$ \\
\hline \multirow[t]{2}{*}{ CPI_1 } & $-0.043 * * *$ & $-0.173 * * *$ & $-0.048 * * *$ & $-0.163 * * *$ & $-0.045 * * *$ & $-0.153 * * *$ & $-0.049 * * *$ & $-0.158 * * *$ & $-0.049 * * *$ & $-0.158 * * *$ \\
\hline & $(0.01)$ & $(0.03)$ & $(0.01)$ & $(0.04)$ & $(0.01)$ & $(0.03)$ & $(0.01)$ & $(0.03)$ & $(0.01)$ & $(0.03)$ \\
\hline \multirow[t]{2}{*}{ PCRED } & 0.001 & -0.00 & 0.00 & -0.005 & 0.00 & -0.001 & -0.001 & -0.003 & -0.001 & -0.002 \\
\hline & $(0.00)$ & $(0.00)$ & $(0.00)$ & $(0.00)$ & $(0.00)$ & $(0.00)$ & $(0.00)$ & $(0.00)$ & $(0.00)$ & $(0.00)$ \\
\hline \multirow[t]{2}{*}{ TOR_5 } & -0.449 & $-2.446 * * *$ & $-1.011 *$ & $-3.181 * * *$ & -0.541 & $-2.59 * * *$ & -0.40 & $-2.404 * * *$ & -0.664 & $-2.399 * * *$ \\
\hline & $(0.49)$ & $(0.88)$ & $(0.54)$ & (1.01) & $(0.50)$ & $(0.84)$ & $(0.51)$ & $(0.82)$ & $(0.51)$ & $(0.82)$ \\
\hline \multirow[t]{2}{*}{$\mathrm{EXCH}$} & $0.274 * * *$ & $0.468 * * *$ & $0.245^{* * *}$ & $0.429 * * *$ & $0.281 * * *$ & $0.456^{* * *}$ & $0.296 * * *$ & $0.475^{* * *}$ & $0.306^{* * *}$ & $0.475 * * *$ \\
\hline & $(0.03)$ & $(0.07)$ & $(0.04)$ & (0.09) & $(0.03)$ & $(0.06)$ & $(0.04)$ & $(0.06)$ & $(0.04)$ & $(0.06)$ \\
\hline \multirow[t]{2}{*}{ OPEN } & $-0.006 * *$ & -0.004 & $-0.006 * *$ & -0.002 & -0.003 & 0.003 & -0.003 & 0.003 & -0.002 & 0.003 \\
\hline & $(0.00)$ & $(0.00)$ & $(0.00)$ & $(0.00)$ & $(0.00)$ & $(0.00)$ & $(0.00)$ & $(0.00)$ & $(0.00)$ & $(0.00)$ \\
\hline \multirow[t]{2}{*}{ NUM_IT } & $0.094 * * *$ & $0.227 * * *$ & $0.066 * * *$ & $0.174 * * *$ & $0.094 * * *$ & $0.192 * * *$ & $0.071 * * *$ & $0.187 * * *$ & $0.093 * * *$ & $0.188 * * *$ \\
\hline & $(0.01)$ & $(0.04)$ & $(0.01)$ & $(0.05)$ & $(0.01)$ & $(0.03)$ & $(0.01)$ & $(0.03)$ & $(0.01)$ & $(0.03)$ \\
\hline \multirow[t]{2}{*}{ TAX_REV_1 } & $0.021 * *$ & $0.066 * * *$ & & & & & & & & \\
\hline & $(0.01)$ & $(0.02)$ & & & & & & & & \\
\hline \multirow[t]{2}{*}{ POLITY2 } & & & $0.109 * * *$ & $0.543 * * *$ & & & & & & \\
\hline & & & $(0.02)$ & $(0.17)$ & & & & & & \\
\hline \multirow[t]{2}{*}{ GSTAB } & & & & & -0.055 & -0.125 & & & & \\
\hline & & & & & $(0.05)$ & $(0.08)$ & & & & \\
\hline $\mathrm{Nb}$. of observations & 501 & 501 & 515 & 515 & 473 & 473 & 396 & 396 & 439 & 439 \\
\hline Pseudo-R ${ }^{2}$ & 0.43 & 0.70 & 0.48 & 0.74 & 0.40 & 0.65 & 0.35 & 0.62 & 0.41 & 0.64 \\
\hline
\end{tabular}


Table 5: Matching estimates of treatment effect on the level of public revenue (robustness checks)

\begin{tabular}{|c|c|c|c|c|c|c|c|}
\hline & \multicolumn{7}{|c|}{ Matching algorithms } \\
\hline & \multicolumn{3}{|c|}{ Nearest-neighbor matching } & \multicolumn{3}{|c|}{ Radius matching } & \multirow{2}{*}{$\begin{array}{l}\text { Kernel } \\
\text { matching } \\
\text { (7) }\end{array}$} \\
\hline & $\begin{array}{l}n=1 \\
(1)\end{array}$ & $\begin{array}{l}\mathrm{n}=3 \\
(2)\end{array}$ & $\begin{array}{l}n=5 \\
(3)\end{array}$ & $\begin{array}{l}r=0.04 \\
(4)\end{array}$ & $\begin{array}{l}r=0.02 \\
(5)\end{array}$ & $\begin{array}{l}r=0.01 \\
(6)\end{array}$ & \\
\hline Average Treatment on Treated (ATT) & \multicolumn{7}{|c|}{ Partial adoption } \\
\hline Adding lagged tax revenue & $\begin{array}{l}\text { 2.12** } \\
(0.91)\end{array}$ & $\begin{array}{l}\mathbf{1 . 0 4} \\
(1.24)\end{array}$ & $\begin{array}{l}\mathbf{1 . 0 3} \\
(1.09)\end{array}$ & $\begin{array}{l}\mathbf{1 . 2 8} \\
(0.97)\end{array}$ & $\begin{array}{l}\mathbf{0 . 2 2} \\
(1.22)\end{array}$ & $\begin{array}{l}\mathbf{0 . 1 6} \\
(1.66)\end{array}$ & $\begin{array}{l}\mathbf{1 . 4 3} \\
(0.93)\end{array}$ \\
\hline Adding Polity2 & $\begin{array}{l}\mathbf{3 . 0 3} * * \\
(1.51)\end{array}$ & $\begin{array}{l}\mathbf{2 . 8 6} * \\
(1.68)\end{array}$ & $\begin{array}{l}\mathbf{2 . 6 2} * \\
(1.50)\end{array}$ & $\begin{array}{l}3.21 * * \\
(1.48)\end{array}$ & $\begin{array}{l}3.14 * \\
(1.71)\end{array}$ & $\begin{array}{l}\mathbf{2 . 6 8} \\
(1.99)\end{array}$ & $\begin{array}{l}\mathbf{3 . 0 5}^{* *} * \\
(1.43)\end{array}$ \\
\hline Adding government stability & $\begin{array}{l}\mathbf{3 . 8 3} * * * \\
(1.40)\end{array}$ & $\begin{array}{l}\mathbf{4 . 4 5} * * * \\
(1.68)\end{array}$ & $\begin{array}{l}4.37 * * * \\
(1.44)\end{array}$ & $\begin{array}{l}\mathbf{4 . 2 8} * * * \\
(1.40)\end{array}$ & $\begin{array}{l}\mathbf{4 . 4 4} * * * \\
(1.49)\end{array}$ & $\begin{array}{l}4.20 * * \\
(1.84)\end{array}$ & $\begin{array}{l}\mathbf{4 . 4 0} * * * \\
(1.38)\end{array}$ \\
\hline Post 1990-sample & $\begin{array}{l}\text { 3.39** } \\
(1.33)\end{array}$ & $\begin{array}{l}\text { 4.95**** } \\
(1.56)\end{array}$ & $\begin{array}{l}\mathbf{4 . 7 6}^{* * * *} \\
(1.44)\end{array}$ & $\begin{array}{l}\mathbf{5 . 1 5} * * * \\
(1.46)\end{array}$ & $\begin{array}{l}\mathbf{5 . 3 1} * * * \\
(1.66)\end{array}$ & $\begin{array}{l}\mathbf{4 . 4 1} * * \\
(1.84)\end{array}$ & $\begin{array}{l}\mathbf{4 . 9 0} * * * * \\
(1.38)\end{array}$ \\
\hline No hyperinflation periods & $\begin{array}{l}\mathbf{4 . 0 2} * * * \\
(1.33) \\
\end{array}$ & $\begin{array}{l}4.40 * * * \\
(1.52)\end{array}$ & $\begin{array}{l}4.52 * * * \\
(1.47)\end{array}$ & $\begin{array}{l}\mathbf{4 . 6 7} * * * \\
(1.42)\end{array}$ & $\begin{array}{l}\mathbf{4 . 4 2} * * * \\
(1.63)\end{array}$ & $\begin{array}{l}\mathbf{3 . 8 4} * * \\
(1.91) \\
\end{array}$ & $\begin{array}{l}\mathbf{4 . 7 2} * * * \\
(1.35)\end{array}$ \\
\hline & \multicolumn{7}{|c|}{ Fully-fledged adoption } \\
\hline \multicolumn{8}{|l|}{ Average Treatment on Treated (ATT) } \\
\hline Adding lagged tax revenue & $\begin{array}{l}\mathbf{2 . 1 0} \\
(1.59)\end{array}$ & $\begin{array}{l}\text { 4.10*** } \\
(2.10)\end{array}$ & $\begin{array}{l}\text { 4.01** } \\
(1.94)\end{array}$ & $\begin{array}{l}\mathbf{3 . 0 1} \\
(2.01)\end{array}$ & $\begin{array}{l}\mathbf{2 . 2 4} \\
(2.60)\end{array}$ & $\begin{array}{l}\mathbf{1 . 6 8} \\
(3.48)\end{array}$ & $\begin{array}{l}\text { 3.65** } \\
(1.82)\end{array}$ \\
\hline Adding Polity2 & $\begin{array}{l}\text { 4.15* } \\
(2.17)\end{array}$ & $\begin{array}{l}4.50 * \\
(2.46)\end{array}$ & $\begin{array}{l}\text { 4.10* } \\
(2.37)\end{array}$ & $\begin{array}{l}3.90 \\
(2.74)\end{array}$ & $\begin{array}{l}3.97 \\
(3.33)\end{array}$ & $\begin{array}{l}\mathbf{0 . 5 6} \\
(4.41)\end{array}$ & $\begin{array}{l}\text { 4.39* } \\
(2.58)\end{array}$ \\
\hline Adding government stability & $\begin{array}{l}\mathbf{6 . 9 6}^{* * * * *} \\
(1.71)\end{array}$ & $\begin{array}{l}\mathbf{6 . 8 7} * * * \\
(2.27)\end{array}$ & $\begin{array}{l}\mathbf{6 . 9 4} * * * \\
(2.18)\end{array}$ & $\begin{array}{l}\text { 7.59**** } \\
(2.34)\end{array}$ & $\begin{array}{l}7.79 * * * \\
(2.79)\end{array}$ & $\begin{array}{l}\text { 7.17** } \\
(3.43)\end{array}$ & $\begin{array}{l}7.66 * * * \\
(2.16)\end{array}$ \\
\hline Post 1990-sample & $\begin{array}{c}\mathbf{6 . 5 6}^{* * * *} \\
(1.86)\end{array}$ & $\begin{array}{l}7.94 * * * \\
(2.22)\end{array}$ & $\begin{array}{c}7.36 * * * \\
(2.16)\end{array}$ & $\begin{array}{c}\text { 8.24*** } \\
(2.23)\end{array}$ & $\begin{array}{c}\mathbf{8 . 0 0} * * * \\
(2.64)\end{array}$ & $\begin{array}{c}\text { 8.39*** } \\
(3.36)\end{array}$ & $\begin{array}{c}\mathbf{8 . 3 3} * * * \\
(2.13)\end{array}$ \\
\hline No hyperinflation periods & $\begin{array}{l}\mathbf{6 . 5 7 * * * *} \\
(1.76)\end{array}$ & $\begin{array}{l}7.94 * * * \\
(2.18)\end{array}$ & $\begin{array}{l}\mathbf{7 . 2 9} * * * \\
(2.15)\end{array}$ & $\begin{array}{l}\mathbf{8 . 3 4} * * * \\
(2.25) \\
\end{array}$ & $\begin{array}{l}\mathbf{8 . 6 3} * * * \\
(2.63)\end{array}$ & $\begin{array}{l}\mathbf{8 . 5 0} * * * \\
(3.31)\end{array}$ & $\begin{array}{l}\mathbf{8 . 3 4} * * * \\
(2.23)\end{array}$ \\
\hline
\end{tabular}

Note: A 0.06 fixed bandwidth and an Epanechnikov kernel are used for kernel regression matching. Bootstrapped standard errors are reported in parentheses (1000 replications). *, **, *** refer to statistical significance at the $10 \%, 5 \%$ and $1 \%$ respectively.

\section{Conclusion}

Previous empirical studies focused on the impact of IT adoption on macroeconomic performances. In this paper, we attempt to assess whether the adoption of this monetary policy framework, by maintaining inflation at low levels, encourages the government to improve the collection of domestic tax revenue in order to recoup the loss of seigniorage revenue due to a tighter monetary policy. Using a propensity score matching approach, we find that most of the estimated ATTs on the level of total public revenue are positive, highly significant, and large in magnitude. Moreover, results are robust to different alternative specifications. Indeed, our empirical results show that, on average, the adoption of IT has led to an augmentation of public revenue collection in emerging market economies. 
These empirical findings suggest therefore that the absence of fiscal dominance, i.e. a sound fiscal policy, is not a fundamental precondition for the adoption of IT, relative to other prerequisites such as central bank independence or the flexibility of the exchange regime. In other words, an unsound fiscal policy should not constitute an impediment to the adoption of IT by emerging economies, since this monetary policy framework may help constrain fiscal policy. The success and the sustainability over the medium term of IT will depend more on the ability of the authorities to plan and drive institutional reforms after adopting IT, in particular reforms aiming to modernize tax and customs administrations.

\section{Acknowledgements}

I would like to thank Christophe Hurlin, Grégory Levieuge, Jean-Paul Pollin, Patrick Villieu and, participants at LEO Seminar and at $5^{\text {th }}$ Annual International Symposium on Economic Theory, Policy and Applications (Athens, 26-29 July 2010) for their useful comments and suggestions. 


\section{References}

Amato, J.D., Gerlach, S., 2002. Inflation targeting in emerging market and transition economies: Lessons after a decade. European Economic Review 46 (4-5), 781-790.

Armas, A., Grippa, F., 2006. Inflation targeting in a dollarized economy: The Peruvian experience, in: Armas, A., Ize, A., Levy Yeyati, E. (Eds.), Financial Dollarization: The Policy Agenda. Palgrave Macmillan, New York, pp. 115-138.

Ball, L., Sheridan, N., 2003. Does inflation targeting matter? NBER Working Paper No. 9577, Cambridge, Massachusetts.

Batini, N., Laxton, D., 2006. Under what conditions can inflation targeting be adopted? The experience of emerging markets. Central Bank of Chile Working Paper No. 406.

Bernanke, B.S., Laubach, T., Mishkin, F.S., Posen, A.S., 1999. Inflation targeting: Lessons from the international experience. Princeton University Press.

Brito, R.D., Bystedt, B., 2010. Inflation targeting in emerging economies: Panel evidence. Journal of Development Economics 91 (2), 198-210.

Brodaty, T., Crépon, B., Fougère, D., 2007. Les méthodes micro-économétriques d'évaluation et leurs applications aux politiques actives d'emploi. Economie et prévision 177 (1), 93-118.

Caliendo, M., Kopeinig, S., 2007. Some practical guidance for the implementation of propensity score matching. Journal of Economic Surveys 22 (1), 31-72.

Carare, A., Schaechter, A., Stone, M., 2002. Establishing initial conditions in support of inflation targeting. IMF Working Paper 02/102.

Castellani, F., Debrun, X., 2001. Central bank independence and the design of fiscal institutions. IMF Working Paper 01/205.

Chambas, G., 2005. Afrique au Sud du Sahara: Mobiliser des ressources fiscales pour le développement. Economica.

Cukierman, A., Edwards, S., Tabellini, G., 1992. Seigniorage and political instability. American Economic Review 82 (3), 537-555.

Dehejia, R., Wahba, S., 1999. Causal effects in non-experimental studies: Re-evaluating the evaluation of training programs. Journal of the American Statistical Association 94, 10531062.

Dreher, A., Sturm, J.E., De Haan, J., 2008. Does high inflation causes central bankers lose their job? Evidence based on a new dataset. European Journal of Political Economy 24 (4), 778-787.

Ehrhart, H., 2009. Assessing the relationship between democracy and domestic taxes in developing countries. Etudes et Documents E 2009.30, Centre d'Etudes et de Recherches sur le Développement International.

Ehrhart, H., Minea, A., Villieu, P., 2009. Deficit, seigniorage and the growth Laffer curve in developing countries, Etudes et Documents E 2009.26, Centre d'Etudes et de Recherches sur le Développement International. 
Faust, J., Henderson, D.W., 2004. Is inflation targeting best-practice monetary policy? Federal Reserve Bank of St. Louis Review 86 (4), 117-143.

Fraga, A., Goldfajn, I., Minella, A., 2003. Inflation targeting in emerging market economies. NBER Working Paper No. 10019, Cambridge, Massachusetts.

Gerlach, S., 1999. Who targets inflation explicitly? European Economic Review 43 (7), 1257 1277.

Gupta, A.S., 2007. Determinants of tax revenue efforts in developing countries. IMF Working Paper 07/184.

Heckman, J.J., Lalonde, R., Smith, J., 1999. The economics and econometrics of active labor market programs, in: Ashenfelter, O., Card, D. (Eds.), Handbook of Labor Economics, vol. 3. Amsterdam, North-Holland, pp. 1865-2097.

Heckman, J.J., Ichimura, H., Todd, P., 1998. Matching as an econometric evaluation estimator. Review of Economic Studies 65 (2), 261-294.

Huang, H., Wei, S-J., 2006. Monetary policies for developing countries: The role of institutional quality. Journal of International Economics 70 (1), 239-252.

Joyce, P.J., Nabar, M. 2009. Sudden stops, banking crises and investment collapses in emerging markets. Journal of Development Economics 90 (2), 314-322.

Khandker, S.R., Koolwal, G.B., Samad, H.A., 2010. Handbook on impact evaluation: Quantitative methods and practices. The World Bank, Washington D.C.

Leuven, E., Sianesi, B., 2003. PSMATCH2: Stata module to perform full Mahalanobis and propensity score matching, common support graphing, and covariate imbalance testing. Available at http://ideas.repec.org/c/boc/bocode/s432001.html.

Levya, G., 2008. The choice of inflation targeting. Central Bank of Chile Working Paper No. 475.

Lin, S., Ye, H., 2009. Does inflation targeting make a difference in developing countries? Journal of Development Economics 89 (1), 118-123.

Lin, S., Ye, H., 2007. Does inflation targeting really make a difference? Evaluating the treatment effect of inflation targeting in seven industrial countries, Journal of Monetary Economics 54 (8), 2521-2533.

Lucotte, Y., 2009. Central bank independence and budget deficits in developing countries: New evidence from panel data analysis. Document de Recherche du LEO No. 2009-19.

Masciandaro, D., Tabellini, G., 1987. Monetary regimes and fiscal deficits: A comparative analysis, in: Cheng, H.S. (Ed.), Monetary Policy in Pacific Basin Countries. Dordrecht: Kluwer, pp. 125-152.

Masson, P.R., Savastano, M.A., Sharma, S., 1997. The scope for inflation targeting in developing countries. IMF Working Paper 97/130. 
Minea, A., Villieu, P., 2009a. Can inflation targeting promote institutional quality in developing countries? The $26^{\text {th }}$ Symposium on Money, Banking and Finance, University of Orléans, 25-26 June 2009.

Minea, A., Villieu, P., 2009b. Threshold effects in monetary and fiscal policies in a growth model: Assessing the importance of the financial system. Journal of Macroeconomics 31 (2), 304-319.

Mishkin, F.S., 2000. Inflation targeting in emerging-market countries. American Economic Review 90 (2), 105-109.

Mishkin, F.S., Schmidt-Hebbel, K., 2007. Does inflation targeting make a difference? NBER Working Paper No. 12876, Cambridge, Massachusetts.

Montiel, P.J., 2003. Macroeconomics in emerging markets. Cambridge University Press, Cambridge, UK.

Pétursson, T., 2004. Formulation of inflation targeting around the world. Monetary Bulletin 2004/1, Central Bank of Iceland, 57-84.

Reinhart, C.S., Rogoff, K.S., 2004. The modern history of exchange rate arrangements: A reinterpretation. The Quarterly Journal of Economics 119 (1), 1-48.

Rosenbaum, P., Rubin, D., 1983. The central role of the propensity score in observational studies for causal effects. Biometrika 70 (1), 41-55.

Rubin, D., 2007. The design versus the analysis of observational studies for causal effects: Parallels with the design of randomized trials. Statistics in Medicine 26 (1), 20-36.

Rubin, D., 1974. Estimating causal effects of treatments in randomized and non randomized studies. Journal of Educational Psychology 66 (5), 688-701.

Tanzi, V., 1992. Structural factors and tax revenue in developing countries: A decade of evidence, in: Goldin, I., Winters, A. (Eds.), Open Economies: Structural Adjustment and Agriculture. Cambridge University Press, Cambridge, UK, pp. 267-281.

Vega, M., Winkelried, D., 2005. Inflation targeting and inflation behavior: A successful story? International Journal of Central Banking 1 (3), 153-175.

World Bank, 2008. World Development Indicators, CD-Rom. The World Bank, Washington D.C.

World Economic Outlook, 2001. International Monetary Fund. May. 


\section{Appendix A. Variables definitions and sources}

\begin{tabular}{|c|c|}
\hline Variables & Definition and source \\
\hline $\mathrm{EXCH}$ & $\begin{array}{l}\text { De facto "fine" classification of exchange rate regimes: polytomic variable taking values from } 1 \text { (hard pegs) to } 14 \\
\text { (freely falling). Source: Reinhart and Rogoff }(2004 ; 2009 \text { update). }\end{array}$ \\
\hline GDPPCG & Real per capita GDP growth. Source: World Development Indicators (2008). \\
\hline GSTAB & $\begin{array}{l}\text { to stay in office, and taking values from } 0 \text { (very low stability) to } 12 \text { (very high stability). This variable is the sum of } \\
\text { three subcomponents (government unity, legislative strength, and popular support), each with a maximum score of } \\
\text { four points and a minimum score of zero point. Source: International Country Risk Guide. }\end{array}$ \\
\hline CPI_1 & $\begin{array}{l}\text { One-year lagged inflation rate, measured by annual percentage change of consumer prices. Source: World } \\
\text { Development Indicators (2008). }\end{array}$ \\
\hline NUM_IT & $\begin{array}{l}\text { Number of industrialized and emerging countries that have adopted IT at the period } t \text {. Source: Author's calculations } \\
\text { based on Levya (2008). }\end{array}$ \\
\hline OPEN & $\begin{array}{l}\text { Trade openness is the sum of exports and imports of goods and services as a share of GDP. Source: World } \\
\text { Development Indicators (2008). }\end{array}$ \\
\hline TAX_REV & Total public revenue as a share of GDP. Source: Center for Studies and Research on International Development. \\
\hline TO & $\begin{array}{l}\text { De facto central bank independence measured by the turnover rate of central bank governors based on } 5 \text {-years } \\
\text { averages. Source: Author's calculations based on central bank websites and Dreher et al. ( } 2008 \text {; april } 2009 \text { update). }\end{array}$ \\
\hline
\end{tabular}

\section{Appendix B. Summary Statistics}

\begin{tabular}{|c|c|c|c|c|c|c|}
\hline Variables & Obs. & Missing obs. & Mean & Std. Dev. & Min & Max \\
\hline & \multicolumn{6}{|c|}{ Inflation targeting countries (1980-2004) } \\
\hline $\mathrm{EXCH}$ & 307 & 18 & 10.07 & 3.12 & 2 & 14 \\
\hline GDPPCG & 303 & 22 & 1.96 & 4.18 & -13.87 & 11.81 \\
\hline GSTAB & 264 & 61 & 7.12 & 1.97 & 1 & 11 \\
\hline CPI & 310 & 15 & 97.91 & 529.13 & -0.41 & 7481.66 \\
\hline OPEN & 305 & 20 & 60.15 & 29.17 & 14.39 & 147.76 \\
\hline PCRED & 300 & 25 & 52.12 & 31.39 & 9.25 & 165.71 \\
\hline POLITY2 & 312 & 13 & 5.12 & 5.45 & -9 & 10 \\
\hline TAX_REV & 227 & 98 & 25.44 & 10.11 & 6.5 & 52.2 \\
\hline \multirow[t]{2}{*}{ TOR_5 } & 325 & 0 & 0.27 & 0.26 & 0 & 1.2 \\
\hline & \multicolumn{6}{|c|}{ Non-inflation targeting countries (1980-2004) } \\
\hline $\mathrm{EXCH}$ & 397 & 28 & 8.49 & 3.82 & 2 & 14 \\
\hline GDPPCG & 409 & 16 & 1.99 & 5.05 & -16.51 & 16.23 \\
\hline GSTAB & 340 & 85 & 7.41 & 2.24 & 1.83 & 12 \\
\hline CPI & 380 & 45 & 44.66 & 210.99 & -1.41 & 3079.81 \\
\hline OPEN & 399 & 26 & 60.97 & 40.12 & 11.54 & 228.87 \\
\hline PCRED & 378 & 47 & 40.73 & 34.98 & 7.17 & 210.42 \\
\hline POLITY2 & 400 & 25 & 0.96 & 6.59 & -10 & 9 \\
\hline TAX_REV & 312 & 113 & 22.47 & 7.84 & 3.01 & 46.1 \\
\hline TOR_5 & 405 & 20 & 0.27 & 0.25 & 0 & 1.2 \\
\hline
\end{tabular}

